\title{
Short Communication: Serratia rubidaea as contaminant in laboratory environment
}

\author{
DEWI PETI VIRGIANTI \\ Program of Medical Laboratory Technique, Sekolah Tinggi Ilmu Kesehatan Bakti Tunas Husada. Jl. Cilolohan 36 Tasikmalaya 46115, West Java, \\ Indonesia. Tel.: +62-81312928444, email: dewivirgianti@gmail.com
}

Manuscript received: 11 September 2020. Revision accepted: 19 January 2021.

\begin{abstract}
Virgianti DP. 2021. Short Communication: Serratia rubidaea as contaminant in laboratory environment. Nusantara Bioscience 13: 47-51. There have been many cases of bacterial contamination in the laboratory. The bacterial genera identified as contaminants are Bacillus, Staphylococcus, Micrococcus, Pseudomonas, Shigella and Serratia. These bacteria are classified as nonpathogenic and pathogenic bacteria that can interfere with the test and potentially develop false-positive results. The present research has shown that red-colored contaminant bacteria develop in unused sterile media in our laboratory. Based on related information, Serratia marcescens is a red bacterial species that have been reported as a contaminant in the laboratory. The purpose of this study was to identifiy contaminant bacteria at the molecular level. Based on the phylogenetic characterization using the 16S rDNA gene region, this red contaminant bacterium was identified as Serratia rubidaea.
\end{abstract}

Keywords: Contamination, environment, gene barcoding, red bacteria, Serratia

\section{INTRODUCTION}

Contamination is an important concern in biological laboratories. They can be categorized into three major groups physical, chemical, and biological. Bacteria, mold, yeast, viruses, and mycoplasma are the most common biological contaminants (Abatenh et al. 2018). Bacterial contamination can occur in numerous laboratories, including animal and plant laboratories ( $\mathrm{Li}$ et al. 2018), health faculty microbiology laboratories (Lutpiatina 2015), university microbiology laboratories (Ghayoor et al. 2015), as well as in hospital microbiology laboratories ( $\mathrm{Ng}$ et al. 2011; Konar and Das 2013). Sources of contamination can come from a variety of sources, including air and surfaces (Konar and Das 2013). Sources of contaminated items include tables, floors, clothing, laboratory surfaces such as incubators, microscopes, computers, phones, and water taps ( $\mathrm{Ng}$ et al. 2011; Ghayoor et al. 2015). In addition, contamination can derive from the body parts of laboratory staff, such as the hands (Konar and Das 2013; Ng et al 2011).

According to Li et al. (2018), the number of microbial contaminants in animal laboratories and bacterial laboratories is found to be higher than in plant laboratories. These contaminant bacteria are pathogenic and nonpathogenic. Common bacterial genera as contaminants in the laboratory include Bacillus, Staphylococcus, and Micrococcus (Ghayoor et al. 2015; Konar and Das 2013). Pathogenic bacteria such as Methicillin-Resistant Staphylococcus aureus (MRSA), Pseudomonas aeruginosa, Salmonella spp. and Enterobacteriaceae have also been identified as contaminants, especially in hospital microbiology laboratories, potentially giving false-positive test results (Ng et al. 2011). Environmental and human influences have a major impact on the diversity and dynamics of microbial contaminants ( $\mathrm{Li}$ et al. 2018), as well as the usage of gloves and handwashing, which are very successful in minimizing pathogenic bacterial contamination in the hospital microbiology laboratory $(\mathrm{Ng}$ et al. 2011). In addition, proper disinfection and sterilization are needed to eliminate contaminant microorganisms and personal hygiene of laboratory staff is also required (Konar and Das 2013).

In a health education laboratory where microbiology is practiced, contaminant bacteria can interfere with the learning process. The genus Bacillus is the main contaminant of the laboratory (Lutpiatina 2015). In the present research, red bacterial isolates were collected from contaminated media that were kept in the washing area of the glassware in a medical school laboratory. In current reports, red bacteria were found as contaminated bacteria in clinical microbiology laboratory of hospital and identified as Serratia marcescens. The contamination caused a pseudo-outbreak as a result of diagnosis. These contaminant bacteria are found in saline solutions, soaps and disinfectants used in laboratories. This pseudooutbreak emphasizes the importance of laboratory worker ability to perform specimen processing procedures (Dundar et al. 2009). Serratia typically causes neonatal nosocomial outbreaks. This outbreak is associated with personal hygiene, such as hand hygiene (Zingg et al. 2017) and environmental hygiene, such as the value of clean air conditioning, which can become a nosocomial reservoir (Uduman et al. 2002). The genus Serratia is a Enterobacteriaceae member that produces prodigiosin, a non-diffusible red pigment. The habitat of Serratia includes air, water, and soil. It can also be associated with plants, insects, and other animals (Grimont and Grimont 1978). 
Information about the diversity of the contaminant bacteria in the laboratory and the origin of their spread is very essential. Therefore, this study emphasized the molecular characterization of contaminant red bacteria isolated from the culture media in the laboratory.

\section{MATERIALS AND METHODS}

\section{Procedure}

Isolation of red bacteria

Red bacteria were isolated from the contaminated culture medium of Sabouraud Dextrose Agar (SDA) to the Nutrient Agar (NA) medium. The red bacterium was called Bakteri Merah as the code.

\section{Identification of red bacteria}

Identification of red bacteria was based on morphological and molecular characterization. Morphological characterization was performed through observation of colony and Gram staining. Molecular characterization was performed by barcoding the $16 \mathrm{~S}$ rRNA gene using 27F AGAGTTTGATCMTGGCTCAG-3') and 1492R (5'TACGGYTACCTTGTTACGACTT-3') as universal primer for bacteria. DNA genome extraction was carried out using the Fungal/Bacterial Miniprep Kit (Zymo Research, D6005). PCR amplification was conducted with MyTaq HS Red Mix (Bioline) with 1 x $25 \mu \mathrm{L}$ master mix PCR composition consisting of $9.5 \mu \mathrm{L}$ ddH2O, $12.5 \mu \mathrm{L}$ My Taq Red Mix, $2 \mathrm{x}, 1 \mu \mathrm{L} 10 \mu \mathrm{mol} / \mu \mathrm{L}$ 27F primers, $1 \mu \mathrm{L} 10$ $\mu \mathrm{mol} / \mu \mathrm{L} 1492 \mathrm{R}$ primer and $1 \mu \mathrm{L}$ DNA template. PCR was performed with the Agilent SureCycler 8800 Thermocycler. PCR was performed at an initial denaturation step of $95^{\circ} \mathrm{C}$ for $1 \mathrm{~min}$, followed by 35 cycles at $95{ }^{\circ} \mathrm{C}$ for $15 \mathrm{sec}, 52{ }^{\circ} \mathrm{C}$ for $15 \mathrm{sec}$, and a final extension step at $72{ }^{\circ} \mathrm{C}$ for $72 \mathrm{sec}$. PCR products have been purified with the Zymoclean Gel DNA Recovery Kit (Zymo Research). Sequencing was carried out in two ways, carried out commercially by Genetika Science Indonesia. Sequential data assembly was done with BLAST through http:/www.ncbi.nlm.nih.gov/BLAST/.

Evolution analysis was conducted with MEGA7 (Kumar et al. 2016) and using the Neighbor-Joining method to obtain a percentage of the tree repetition in which the taxa cluster was associated with the bootstrap test (1000 repetitions). The evolutionary distance was calculated using the Maximum Composite Likelihood method.

\section{RESULTS AND DISCUSSION}

\section{Purification of red bacteria}

Contaminated SDA medium was sterilized unused medium, but was previously cut into laminar air flow with aseptic tools for other purposes. Contamination occurs when the medium was placed in washing room of glasswares located inside the laboratory. The pure culture of red bacterial colonies showed characteristics of round, medium-sized colonies of 2-3 mm, flat edges, convex elevations, and pink to red color (Figure. 1). Gram staining results exhibited that the bacterium was cocobacili Gramnegative.

\section{Phylogenetic analysis}

Molecular identification was performed to get a confirmed identification of the bacteria. The 16S rRNA sequence was successfully amplified. The PCR product was shown by DNA fragment at 1500 bp (Figure 2). Evolutionary analysis conducted by MEGA7 showed the red bacteria were clustered into $S$. rubidaea (Figure 3 ). The clade of $S$. rubidaea was distinctly distinguished from the other species of Serratia. According to the phylogenetic tree as described in figure 3 , the most closely related strains were S. rubidaea NR_024644 strain JCM 1240 and S. rubidaea NR_114232 strain NBRC 103169. A similar result was obtained from BLASTN result that the similarity of the strain reached $99.65 \%$ identity with $S$. rubidaea NR_024644 strain JCM 1240 and $99.58 \%$ with S. rubidaea NR_114232 strain NBRC 103169. Meanwhile, other clades include other Serratia species namely $S$. ficara, $S$. odorifera, S. marcescens, $S$. ureilytica and the other genus of Cedecea. Based on NCBI information, S. rubidaea NR 024644 strain JCM 1240 is Japan's bacterial strain use $\bar{d}$ as comparative reference in the journal of investigation of the origin of intracellular aerobic gut bacteria symbiont of the Buchnera aphid (Harada et al. 1995).

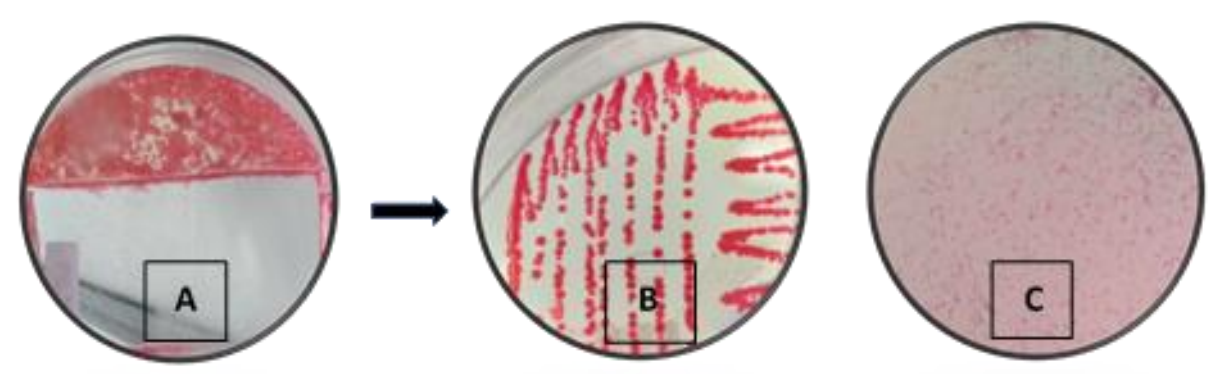

Figure 1. Contaminants of red bacteria grown in unused culture medium (A), pure colonies of red bacteria (B) Cocobacilli Gramnegative bacteria $(\mathrm{C})$ 


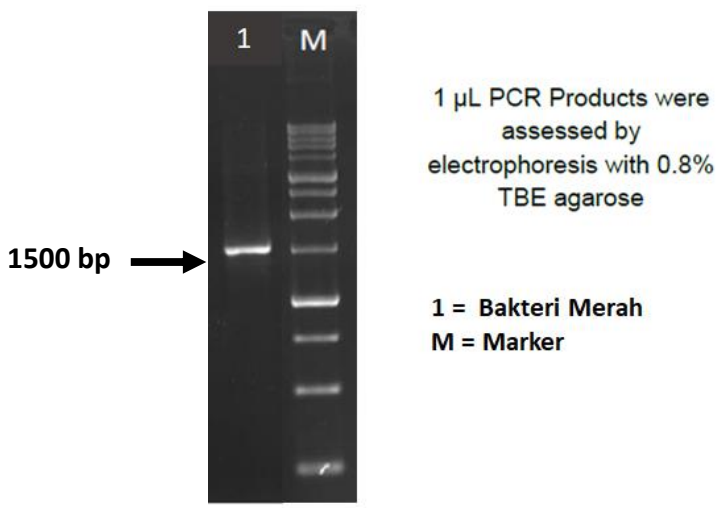

Figure 2. L PCR products were assessed by electrophoresis with 1\% TBE agarose. Red bacteria (Bakteri Merah) (1) and marker (M).

The genus Serratia belongs to the Enterobacteriaceae family and the Gammaproteobacteria class. The genus consists of 15 species, namely S. entomophila, S. ficaria, $S$. fonticola, $S$. glossinae, $S$. grimesii, $S$. liquefaciens, $S$. marcescens, S. nematodiphila, S. odorifera, S. plymuthica, $S$. proteamaculans, $S$. quinivorans, $S$. rubidaea, $S$. symbiotica, and $S$. ureilytica (http://www.catalogueoflife.org) . S. rubidaea was first described in 1940 as Bacterium rubidaea and also as Serratia marinarubra, but was reclassified as $S$. rubidaea (Ewing et al. 1973). There are three subspecies in it: $S$. rubidaea subsp. burdigalensis, $S$. rubidaea subsp. rubidaea, and S. rubidaea subsp. colindalensis (Grimont and Grimont 2006).

The habitat of $S$. rubidaea is not known for certain, but it has reported to have been isolated from foods such as coconuts (Siva et al. 2012), tomato salad (Abd-Alla et al. 2011), green chillies, and milk (Al-Mijalli 2014; Immanuel et al. 2008). It has also been identified as phytopathogen in tulips (Stoyanova and Bogatzevska 2011), epiphytic of Chaetomorpha media seaweed (Pawar et al. 2015) and isolated from soil (Nalini and Parthasarathi 2013).

The presence of $S$. rubidaea in clinical samples is uncommon, but may cause opportunistic infection in several patients who have invasive procedures of surgery or receiving broad-spectrum antimicrobials (Ursua et al. 1996; Gentille et al. 2014; Litterio et al 2002; Yao et al 2016). S. rubidaea has been reported in several research journals, including as a causes of nosocomial urinary tract infections (Menezes et al. 2004), and causes reddish urine color (Kumar et al. 2013). The red pigment of S. rubidaea known as prodigiosin might be associated with urinary tract infection (UTI) and leading to reddish discoloration of urine. This case has been documented in diabetic patients who presented with burning micturition and reddish discoloration (Kumar et al. 2013). As nosocomial urinary tract infection agent, the frequency of $S$. rubidaea appearance in urine samples is the lowest compared to $S$. liquifaciens and S. odorifera (Menezes et al. 2004). The damaged physical structure of hospital facilities, including surgery and obstetric birthing center, leads increasing predisposition of bacterimia in neonatal caused by $S$. rubidaea (Karkey et al. 2018). In addition, it has been reported to cause sepsis, although the case was rare (Okada et al. 2002). Six species of Serratia, namely Serratia ficaria, Serratia fonticola, Serratia odorifera, Serratia plymuthica, Serratia rubidaea and Serratia entomophila are uncommon in clinical studies, but almost all Serratia have been isolated from human clinical specimens and virulence-associated properties have also been reported (Stock et al. 2003).

$S$. rubidea capable of producing extracellular enzymes that play an important role in its opportunistic pathogenicity. Protease, lipase, alkaline phosphatase and polygalacturonase enzymes were detected in $S$. rubidaea which produce at several optimum temperatures (Al-Mijalli 2014). Besides the enzymes, $S$. rubidaea is a source of red pigment prodigiosin, which is very important in biotechnology and pharmacology. Siva et al. (2012) documented the production of pigment prodigiosin in $S$. rubidaea was higher than $S$. marcescens. Prodigiosin has potential clinical significance as it is stated to have antibacterial (Ibrahim et al. 2014), antifungal (Shaikh 2016), antiprotozoal/antimalaria (Papireddy et al. 2011) and promising anticancer activity (Lin et al. 2019; Li et al. 2018).

The cases of $S$. rubidaea contamination have never been documented in laboratories, but this finding proves that $S$. rubidaea can contaminate the stored media of microbial culture in the laboratory environment. Contaminated culture media was sterile media that was no longer used and placed in the laboratory without wrapping in a glassware washing area. It is suspected that the source of the contaminant comes from vector insects such as Drosophila melanogaster, aphid, mites or ants. The vector can enter the unwrapped Petri dishes through the gaps (Pease 1937).

Some Serratia species have been associated with insects. S. marcescens, has been associated with a number of insects such as Nilaparvata lugens Ståll (Priyatno et al. 2011), Plutella xylostella (Indiragandhi et al. 2011), Myrmica ants, and Maculinea (Salvo et al. 2019). S. entomophila also plays a role in the chemical cross-talk in larval stage between of Maculinea and also in the Myrmica ants (Salvo et al. 2019).

In conclusion, $S$. rubidaea has been identified as contaminant bacteria in laboratories. This result provided further knowledge of the variety of contaminant bacteria obtained from the laboratory environment, such as insects as vectors. 


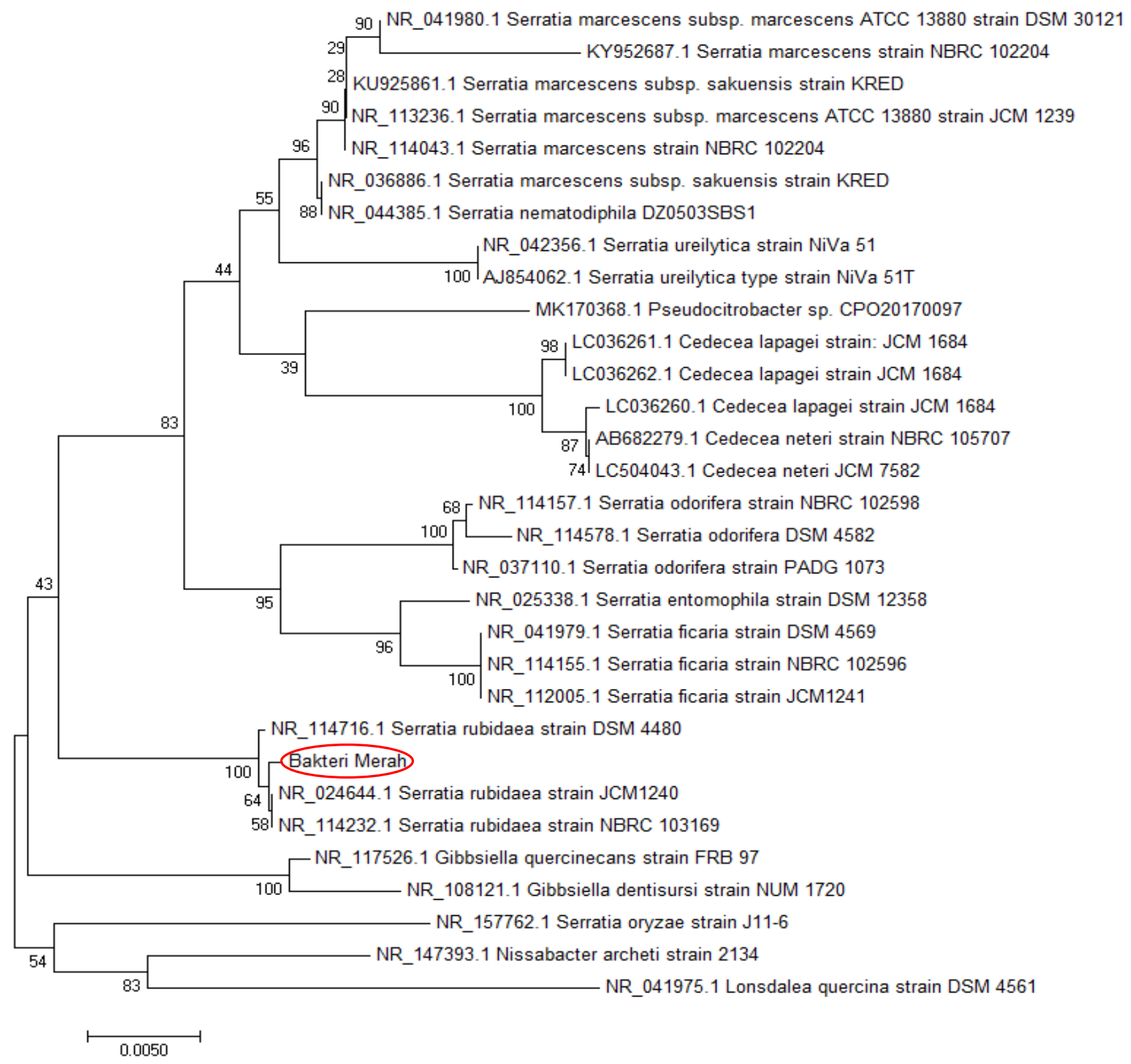

Figure 3. Neighbor-joining dendrograms based on 16S rRNA sequences show a phylogenetic relationship between red bacteria (Bakteri Merah) and a sequence of bacteria obtained from BLAST results. Bootstrap values based on 1000 repetitions are displayed on branch nodes. Phylogenetic trees recognize red bacterial isolates in one clade as Serratia rubidaea

\section{ACKNOWLEDGEMENTS}

This research was funded by P3M STIKes BTH Tasikmalaya, Indonesia.

\section{REFERENCE}

Abatenh E, Gizaw B, Tsegaye Z. 2018. Contamination in a microbiological laboratory. Int J Res Stud Biosci 6 (4): 7-13. DOI: 10.20431/2349-0365.0604002.

Abd-Alla MH, Bashandy SR, Schnell S, Ratering S. 2011. Isolation and characterization of Serratia rubidaea from dark brown spots of tomato fruits. Phytoparasitica 39 (2): 175-183. DOI: 10.1007/S12600011-0148-6.
Al-Mijalli SHS. 2014. Isolation and characterization of plant and human pathogenic bacteria from green pepper (Capsicum annum L.) in Riyadh, Saudi Arabia. Biotech 4: 337-344. DOI 10.1007/s13205-0130136-2.

Dundar D, Meric M, Vahaboglu H, Willke A. 2009. Pseudo-outbreak of Serratia marcescens in a tertiary care hospital. New Microbiol 32: 273-276.

Ewing WH, Davis BR, Fife MA, Lessel EF. 1973. Biochemical characterization of Serratia liquefaciens (Grimes and Hennerty) Bascomb et al. (formerly Enterobacter liquefaciens) and Serratia rubidaea comb. nov. and designation of type and neotype strains. Int $\mathbf{J}$ Syst Bacteriol 23: 217-225.

Gentille D, Pérez M, Centelles MJ. 2014. Bacteremia by a Serratia rubidaea with an atypical quinolones resistance phenotype. Rev Chilena Infectol 31 (3): 351-352.

Ghayoor M, Qadoos A, Bahadar S, Hayat A, Daud M, Hassan A, Ali F, Zeb A, Ur Rahman K, Wahab A, Khattak ZF, Khattak B. 2015. 
Isolation and identification of common contaminants bacteria from working area in microbiology laboratory. J Bio-Mol Sci 3 (2): 74-78.

Grimont F, Grimont PAD. 2006. The genus Serratia. Prokaryotes 6: 219244. DOI: $10.1007 / 0-387-30746-x \_11$.

Grimont PAD, Grimont F. 1978. The genus Serratia. Ann Rev Microbiol 32: 221-248

Harada H, Oyaizu H, Ishikawa H. 1996. A consideration about the origin of aphid Intracellular symbiont in connection with gut bacterial flora. J Gen Appl Microbiol 42: 17-26.

Ibrahim D, Nazari TF, Kassim J, Lim SH. 2014. Prodigiosin-an antibacterial red pigment produced by Serratia marcescens IBRL USM 84 associated with a marine sponge Xestospongia testudinaria. J Appl Pharm Sci 4: 1-6. DOI: 10.7324/JAPS.2014.40101.

Immanuel G, Esakkiraj P, Jebadhas A, Lyapparaj P, Palevesam A. 2008 Investigation of lipase production by milk isolate Serratia rubidaea. Food Technol Biotechnol 46 (1): 60-65.

Indiragandhi P, Anandham R, Sa TM. 2011. Functional significance of insect gut bacteria and their role in host insect processes, development, and crop production. In: Maheshwari DK (ed.) Bacteria in Agrobiology: Plant Growth Responses. DOI: 10.1007/978-3-64220332-9_14. Springer-Verlag Berlin Heidelberg.

Karkey A, Joshi N, Chalised S, Joshi S, Shrestha S, Nguyen TNT, Dongol S, Basnyat B, Baker S, Boinett CJ. 2018. Outbreaks of Serratia marcescens and Serratia rubidaea bacteremia in a central Kathmandu hospital following the 2015 earthquakes. Trans R Soc Trop Med Hyg 112: 467-472. DOI: $10.1093 /$ trstmh/try077.

Konar J, Das S. 2013. Common contaminants of bacteriology laboratory: microbiological paramores. Int J Pharm Sci Invention 2 (11): 2319 6718 .

Kumar S, Bandyopadhyay M, Chatterjee M, Mukhopadhyay P, Pal S, Poddar S, Banerjee P. 2013. Red discoloration of urine caused by Serratia rubidae: A rare case. Avicenna J Med 3 (1): 20-22. DOI: 10.4103/2231-0770.112790.

Kumar S, Stecher G, Tamura K. 2016. MEGA7: Molecular evolutionary genetics analysis version 7.0 for bigger datasets. Mol Biol Evol 33 1870-1874

Litterio ML, Arazi S, Hernandez C. 2012. Isolation of Serratia rubidaea from a mixed infection after a horse bite. Rev Argent Microbiol 44: $272-274$

Li D, Liu J, Wang X, Kong D, Dua W, Li H, Hse CY, Shupe T, Zhou D, Zhao K. 2018. Biological potential and mechanism of prodigiosin from Serratia marcescens Subsp. lawsoniana in human choriocarcinoma and prostate cancer cell lines. Int J Mol Sci 19 (11): 3465. DOI: 10.3390/ijms19113465.

Li X, Zhu X, Wang W, Ning K. 2018. Microbial contamination screening and interpretation for biological laboratory environments. bioRxiv 439570. DOI: 10.1101/439570.

Lin PB, Shen J, Ou PY, Liu LY, Chen ZY, Chu FJ, Wang J, Jin XB. 2019. Prodigiosin isolated from Serratia marcescens in the Periplaneta americana gut and its apoptosis-inducing activity in HeLa cells Oncol Rep 41 (6): 3377-3385. DOI: 10.3892/or.2019.7089.

Lutpiatina L. 2015. Produk urikase dari Bacillus sp. kontaminan laboratorium. Med Lab Technol J 1 (2): 96-101. [Indonesian]

Menezes EA, Cezafar FC, de Sena Andrade MS, de Paula Rocha MVA, Cunha FA. 2004. Frequency of Serratia sp in urine infections of intern patients in the Santa Casa de Misericórdia in Fortaleza. Revista da Sociadade Brasileira de Medicina Tropical 37: 70-71

Nalini S, Parthasarathi R. 2013. Biosurfactant production by Serratia rubidaea SNAU02 isolated from hydrocarbon-contaminated soil and its physicochemical characterization. Bioresour Technol 147: 619622. DOI: 10.1016/j.biortech.2013.08.041

Ng LSY, Teh WT, Ng SK, Eng LC, Tan TY. 2011. Bacterial contamination of hands and the environment in a microbiology laboratory. J Hosp Infect 78: 231-233. DOI: 10.1016/j.jhin.2011.01.025.

Okada T, Yokota E, Matsumoto I. 2002. Community-acquired sepsis by Serratia rubidaea. Kansenshogaku Zasshi. J Jpn Assoc Infect Dis 76 (2): 109-112.

Papireddy K, Smilkstein M, Kelly JX, Salem SM, Alhamadsheh M, Haynes SW, Challis GL, Reynolds KA. 2011. Antimalarial activity of natural and synthetic prodiginines. J Med Chem 54: 5296-5306. DOI: $10.1021 / \mathrm{jm} 200543 \mathrm{y}$.

Pawar R, Mohandass C, Sivaperumal E, Sabu E, Rajasabapathy R, Jagtap T. 2015. Epiphytic marine pigmented bacteria: A prospective source of natural antioxidants. Braz J Microbiol 46 (1): 29-39. DOI: 10.1590/S1517-838246120130353.

Pease D. 1937. The insect menace in the bacteriology laboratory. J Bacteriol 33 (6): 619-624.

Priyatno TP , Dahliani YA, Suryadi Y, Samudra IM, Susilowati DN, Rusmana I, Wibowo BS, Irwan C. 2011. Identifikasi entomopatogen bakteri merah pada wereng batang coklat (Nilaparvata lugens Stål.). Jurnal AgroBiogen 7 (2): 85-95. [Indonesian]

Salvo MD, Calcagnile M, Talà A, Tredici SM, Maffei ME, Schönrogge K, Barbero F, Alifano P. 2019. The microbiome of the MaculineaMyrmica host-parasite interaction. Sci Rep 9: 8048. DOI: 10.1038/s41598-019-44514-7.

Siva R, Subha K, Bhakta D, Ghosh AR, Babu S. 2012. Characterization and enhanced production of prodigiosin from the spoiled coconut. Appl Biochem Biotechnol 166: 187-196. DOI: 10.1007/s12010-0119415-8.

Shaikh Z. 2016. Biosynthesis of prodigiosin and its applications. IOSR J Pharm Biol Sci 11: 1-28. DOI: https://doi.org/10.9790/30081106050128 .

Stock I, Burak S, Sherwood KJ, Gruger T, Wiedemann B. 2003. Natural antimicrobial susceptibilities of strains of 'unusual' Serratia species: S. ficaria, S. fonticola, S. odorifera, S. plymuthica and S. rubidaea. J Antimicrob Chemother 51 (4):865-85.

Stoyanova M, Bogatzevska N. 2011. Phytopathogenic Serratia rubidaea Isolated from Tulips. Sci Technol 1 (6): 20-24.

Uduman SA, Farrukh AS, Nath KNR, Zuhair YH, Ifrah A, Khawla AD, Sunita P. 2002. An outbreak of Serratia marcescens infection in a special-care baby unit of a community hospital in United Arab Emirates: the importance of the air conditioner duct as a nosocomial reservoir. J Hosp Infect 52 (3): 175-180. DOI: 10.1053/jhin.2002.1308.

Ursua PR, Unzaga MJ, Melero P, Iturburu I, Ezpeleta C, Cisterna R. 1996. Serratia rubidaea as an invasive pathogen. J Clin Microbiol 34 (1): 216-217. DOI: 10.1128/JCM.34.1.216-217.1996.

Yao X, Sun Q, Liu W, Yin X, Pei G, Wang Y, An X, Mi Z, Luo Y, Tong Y, Chen S. 2016. Complete genome sequence of Serratia rubidaea isolated in China. Genome Announc 4 (2): e00283. DOI: 10.1128/genomeA.00283-16.

Zingg W, Soulake I, Baud D, Huttner B, Pfister R, Renzi G, Pittet D, Schrenzel J, Francois P. 2017. Management and investigation of a Serratia marcescens outbreak in a neonatal unit in Switzerland - the role of hand hygiene and whole-genome sequencing. Antimicrob Resist Infect Control 6 (125): 1-6. DOI: 10.1186/s13756-017-0285-x. 